\title{
高活性な白金ナノ粒子触媒の開発と 電極触媒としての応用展開
}

\author{
白仁田 沙代子*
}

1. は じめに

一般的に安定であると言われている Pt は，その特性のた め総需要量の $32.5 \%$ が宝飾品用として使われている(1). その 一方で，粒子サイズを小さくしていくと表面特性が変化し， 触媒として高い活性を有することから，自動車用排気ガス浄 化触媒としては宝飾品用を超える $37.1 \%$ という高い割合を占 めている. その他, 化成品や医薬品の中間体, 農薬合成など の産業用が $21.3 \%$ を占めている(1).

このPt を触媒として使用するには，Ptの比表面積が大き くなるようにナノ粒子化される，これまでに様々なナノ粒子 に関する研究は多くなされている(2). 特に, Ptは上述した 通り, 高価かつ希少であるため, 活性な $\mathrm{Pt}$ 金属表面の有効 利用, Pt 使用量の削減技術の開発が必要不可欠である. そ こで, Ptナノ粒子を高分散状態で担持すること, 低 Pt 量で も活性があることを目指し, 紫外光にアクティブな担体材料 を用いて Ptナノ粒子を固定化し，さらに電極触媒としての 展開を試みたので紹介する.

\section{2. 単核 $\mathrm{Ti}$ 種上への $\mathrm{Pt}$ ナノ粒子の固定化}

ここで紹介するのは, 図 1 に示す $\mathrm{Si}$ 骨格で構成されるメ ソポーラスシリカ内に $\mathrm{Ti}$ 種を組み込んだ $\mathrm{Ti}$ 含有メソポー ラスシリカ上に $\mathrm{Pt}$ ナノ粒子を固定化担持する手法であ る(3)(4).ここで, Ti種は単核でメソポーラスシリカの骨格 内に組み込をれるよう $\mathrm{Ti} / \mathrm{Si}$ が0.01の割合になるように調製 し，規則的な細孔構造を有していることをXRD 測定により $2 \theta=2^{\circ}$ 付近にピークが観測されることで確認している。この

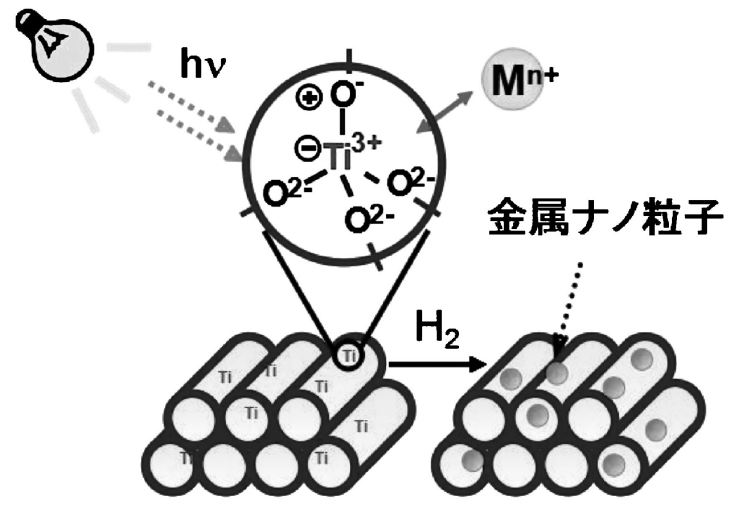

図 1 紫外光照射下に扔ける $\mathrm{Ti}$ 含有メソポーラスシリ カ上への Ptナノ粒子担持の概略図.

単核 $\mathrm{Ti}$ 種は紫外光照射下で, バルクの $\mathrm{TiO}_{2}$ とは異なる励 起種を生成する. バルクの $\mathrm{TiO}_{2}$ に紫外光を照射すると, 電 子と正孔はそれぞれ空間的に離れたサイトに生成し，それぞ れ還元反応と酸化反応に寄与する. 一方, 孤立した単核 $\mathrm{Ti}$ 種では, $\left(\mathrm{Ti}^{3+}-\mathrm{O}^{-}\right)$などの電荷移動型励起種を形成し, 電子 トラップサイト $\left(\mathrm{Ti}^{3+}\right)$ と正孔トラップサイト $\left(\mathrm{O}^{-}\right)$が隣接し た共存状態で反応に寄与する(5). そのため，バルクとは異な る反応活性や反応選択性を示すことが知られている。 また， この $\mathrm{Ti}$ 種は高分散状態で存在しており, Pt の固定化を $\mathrm{Ti}$ 種上で行うと Ptナノ粒子も高分散状態で固定化されること が期待される.

まず, $\mathrm{Ti}$ 含有メソポーラスシリカの調製方法であるが, $\mathrm{Ti}$ 源にチタンテトライソプロポキシド, $\mathrm{Si}$ 源にオルトケイ 酸テトラエチル, 構造規制剂にドデシルアミンを用い加水分

* 長岡技術科学大学大学院工学研究科 ; 助教 ( $=940-2188$ 長岡市上富岡町1603-1)

Development of High Active Pt Nanoparticle and Its Application as Electrocatalyst; Sayoko Shironita (Nagaoka University of Technology, Nagaoka)

Keywords: platinum, catalyst, nano particle, electrocatalyst

2017年 3 月 24 日受理[doi:10.2320/materia.56.508] 


\section{(a) imp-Pt/Ti-HMS}

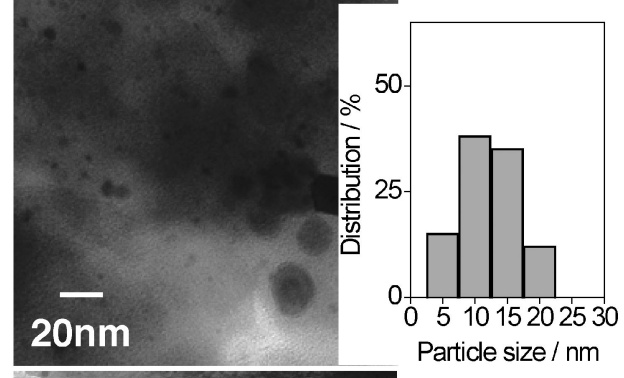

(b) PAD-Pt/TI-HMS

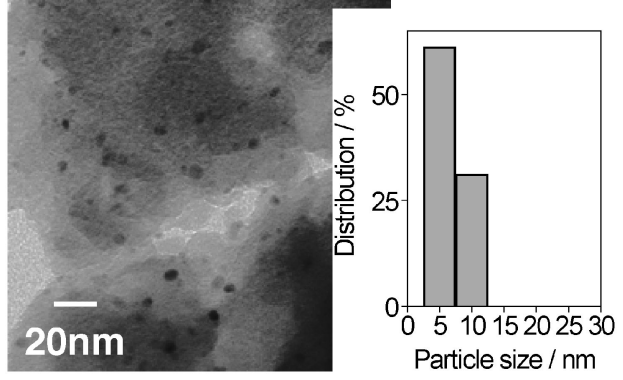

図 2 （a）含浸法で調製した触媒 (imp-Pt/Ti-HMS) と (b) 紫外光照射下で調製した触媒 (PAD-Pt/TiHMS)の TEM 写真と Pt 粒子径のヒストグラム.

解反応により得られた沈殿物をろ過・乾燥 ・焼成した ${ }^{(6)}$ 。そ の後, $\mathrm{Pt}$ を含有する前駆体 $\left(\mathrm{H}_{2} \mathrm{PtCl}_{6}\right)$ 水溶液中に調製した $\mathrm{Ti}$ 含有メソポーラスシリカ粉末を分散させ $100 \mathrm{~W}$ の高圧水 銀ランプを用い, $298 \mathrm{~K}$ 紫外光照射下で攪拌するという簡易 な方法 (光支援析出法 : PAD 法)で Ptナノ粒子を固定化担持 した(3)(4).

比較のために含浸法 (imp)においても $\mathrm{Pt}$ 粒子を $\mathrm{Ti}$ 含有メ ソポーラスシリカ上に担持した. $\mathrm{Pt}$ 前駆体水溶液と $\mathrm{Ti}$ 含有 メソポーラスシリカ粉末を混合し, 減圧下で蒸発乾固させ た. その後, $383 \mathrm{~K}$ で乾燥させ, 水素流通 $(20 \mathrm{~mL} / \mathrm{min})$ 下 $473 \mathrm{~K}$ で 1 時間還元処理を行った.

これらの手法で調製した Ptナノ粒子の TEM 写真と写真 より算出した Pt 粒子径のヒストグラムを図 2 にそれぞれ示 す. 含浸法で調製した方は $\mathrm{Pt}$ 粒子径が 2-20 nm の粒子径を 有して抢り，粒径分布が広くなっていることがわかる。一 方, 紫外光照射下で調製した Pt 粒子は $4 \mathrm{~nm}$ 付近に狭い粒 子径分布を有していることがわかる. 粒子も高分散状態で固 定化されている様子がみてとれる.

ここでこれらの調製した Ptナノ粒子担持触媒を用いて $\mathrm{CO}$ 酸化反応により触媒活性を評価した。条件は, 触媒 0.1 $\mathrm{g}, \mathrm{CO}$ ガス濃度 $1 \%$ ，バランスガスは空気とし， $30 \mathrm{~mL} /$ min で流通させた. その結果を図 3 に示す. 紫外光照射下で 調製した触媒は, 約 $400 \mathrm{~K}$ で転化率 $100 \%$ に達している。一 方, 含浸法の触媒は反応を進める上でより高温で反応させる 必要があることがわかる，よって，このCO酸化反応におい て Pt 粒子の粒子径と分散度が重要であることがわかった.

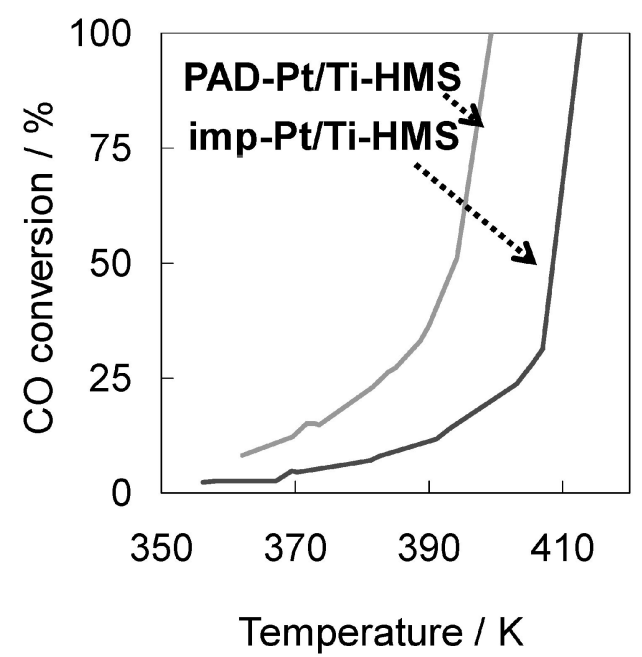

図 3 含浸法で調製した触媒 (imp-Pt/Ti-HMS) と紫外 光照射下で調製した触媒 (PAD-Pt/Ti-HMS)の $\mathrm{CO}$ 酸化反応.

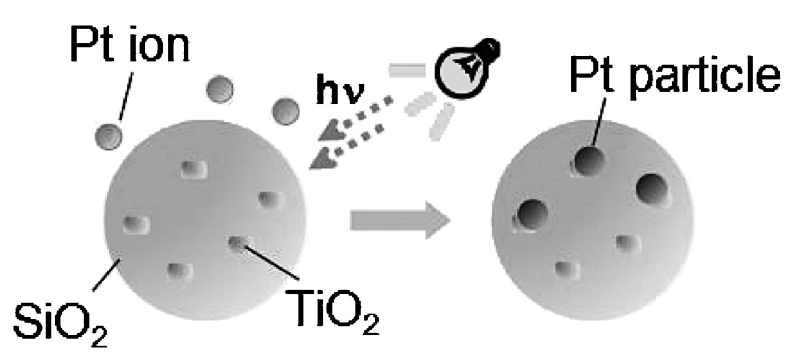

図 4 紫外光照射下に打りる $\mathrm{TiO}_{2}-\mathrm{SiO}_{2}$ 担体材料への $\mathrm{Pt}$ ナノ粒子担持の概略図.

\section{3. 燃料電池用の電極触媒の $\mathrm{Pt}$ 使用量削減}

排気ガス浄化の自動車触媒以外にも, 近年注目されている のは燃料電池用の電極触媒である。これにも Ptナノ粒子は 使用されている. 併せて, この Pt 使用量の低減が燃料電池 自体のコスト削減および本格的な普及に大きく関わってくる と言っても過言ではない。希少金属である Ptの有効利用は 世界的にも重要な課題でもある，そこで，上述の触媒調製法 を電極触媒に応用展開し，図４に示すように Pt 粒子の担持 サイトを制御した系の電極触媒の作製を試みた ${ }^{(7)}$.

ここでは $\mathrm{TiO}_{2}$ と $\mathrm{SiO}_{2}$ の混合粒子 $\left(\mathrm{TiO}_{2}-\mathrm{SiO}_{2}\right)$ を担体材料 として用いた. Si 源にはオルトケイ酸テトラエチル, Ti 源 にはチタンテトライソプロポキシドを用いた. $\mathrm{TiO}_{2}$ の含有 量が5，10，50 mass\%になるように加水分解法により 303 $\mathrm{K}$ で 3 時間攪拌し，万過後に乾燥させ， $673 \mathrm{~K}$ で 30 分間の 焼成を行い $\mathrm{TiO}_{2}-\mathrm{SiO}_{2}$ 粉体とした. その後, $\mathrm{Pt}$ 担持量が 1 mass \% となるように $\mathrm{Pt}$ 前駆体 $\left(\mathrm{H}_{2} \mathrm{PtCl}_{6}\right)$ 水溶液へ得られた $\mathrm{TiO}_{2}-\mathrm{SiO}_{2}$ 粉体を分散させ, 紫外光照射下で 5 時間攪拌し, その後, 万過・乾燥を行い $\mathrm{Pt} / \mathrm{TiO}_{2}-\mathrm{SiO}_{2}$ 電極触媒とした.

得られた電極触媒は, 粉体触媒を電気化学的に評価可能な 多孔質マイクロ電極 ${ }^{(8)}$ に充填させ, 電気化学測定を行った. 
触媒を充填した多孔質マイクロ電極を作用極とし，対極には $\mathrm{Pt}$ コイル，参照極には $\mathrm{Ag} / \mathrm{Ag}_{2} \mathrm{SO}_{4}$ を用いた三電極セルにて 評価した。電解液には $0.5 \mathrm{~mol} / \mathrm{dm}^{3} \mathrm{H}_{2} \mathrm{SO}_{4}$ 水溶液を用いた.

図 5 に不活性ガス $(\mathrm{Ar})$ 雲囲気下での電流一電位曲線を示 す. 比較のために市販の $\mathrm{Pt}$ 担持カーボン $(\mathrm{Pt} / \mathrm{C})$ 粉体触媒の ものも示す. $\mathrm{Pt} / \mathrm{C}$ の曲線はバルクの $\mathrm{Pt}$ に特徵的なプロトン の吸着と脱離に由来するバタフライパターンが観測されてい る ${ }^{(9)}$. 一方, 今回の $\mathrm{Pt} / \mathrm{TiO}_{2}-\mathrm{SiO}_{2}\left(\mathrm{TiO}_{2}: 5,10,50\right.$ mass \%)のいずれの電極触媒に打いて Pt の特徵は得られて

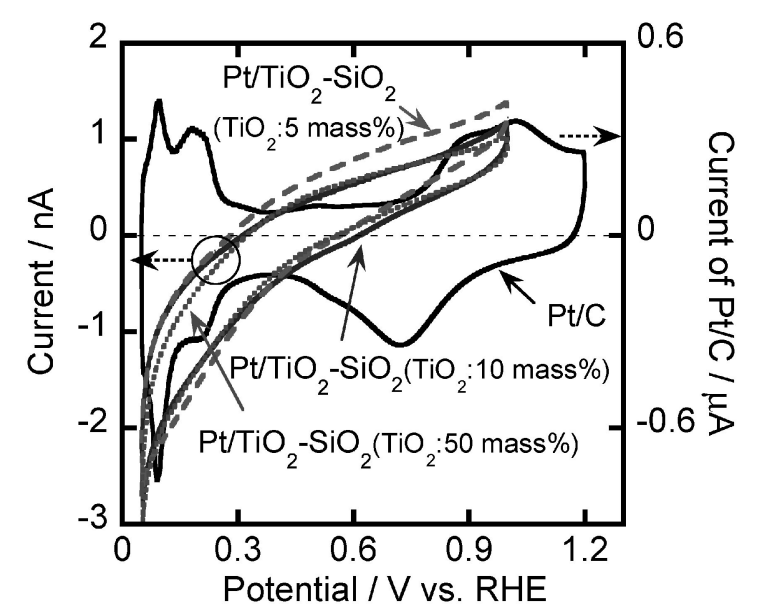

図 $5 \mathrm{Pt} / \mathrm{TiO}_{2}-\mathrm{SiO}_{2}\left(\mathrm{TiO}_{2}: 5,10,50 \mathrm{mass} \%\right)$ と $\mathrm{Pt} / \mathrm{C}$ 電 極触媒の電流一電位曲線.
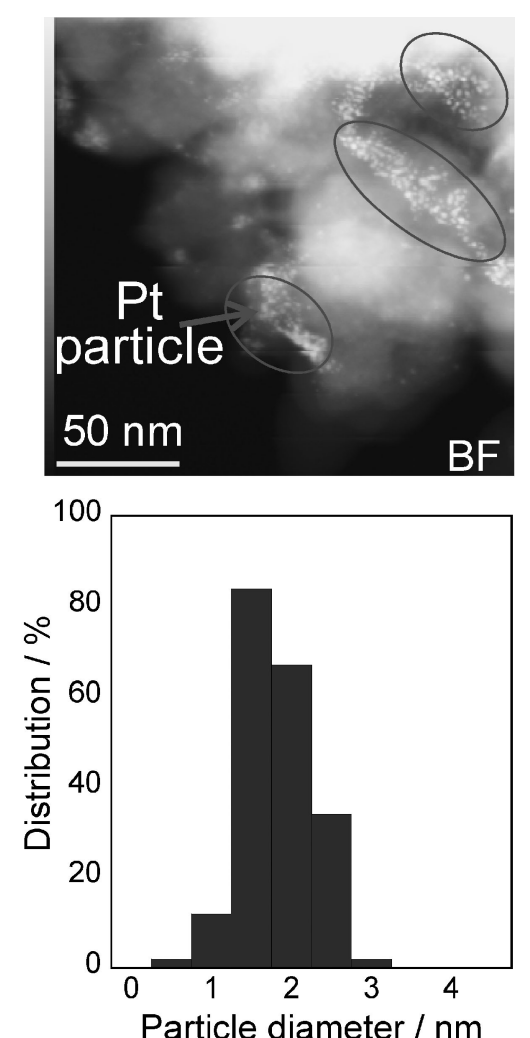

図 $6 \mathrm{Pt} / \mathrm{TiO}_{2}-\mathrm{SiO}_{2}\left(\mathrm{TiO}_{2}: 10\right.$ mass\%)の TEM 写真(上 図)と Pt 粒子径のヒストグラム(下図).
いない。つまり電流一電位曲線からは Ptナノ粒子の担持の 有無は確認できないことがわかる。これは担持量が少ないま たは Pt 粒子径が小さいためであると考えられる。そこで, $\mathrm{TEM}$ 観察および $\mathrm{EDS}$ 分析を行い, $\mathrm{Pt} / \mathrm{TiO}_{2}-\mathrm{SiO}_{2}\left(\mathrm{TiO}_{2}: 10\right.$ mass\%)の結果を図 6 に示す。 小さな斑点部分とそれ以外の 部分で, EDS 分析を行ったところ, 斑点部分には Pt, Ti, Si, $\mathrm{O}$ の信号強度が，それ以外の部分では $\mathrm{Ti}, \mathrm{Si}, \mathrm{O}$ のみが検出 され，確かにPt が担持されていることが確認できた．また TEM 写真より $\mathrm{Pt}$ 粒子径を算出したところ $1.5 \mathrm{~nm}$ に平均粒 径と非常に狭い粒径分布を有するヒストグラムが得られた。

次に, 電極触媒の評価として燃料電池のアノード反応であ る水素酸化反応を行った. 電解液には $\mathrm{H}_{2}$ 飽和 $0.5 \mathrm{~mol} / \mathrm{dm}^{3}$ $\mathrm{H}_{2} \mathrm{SO}_{4}$ 水溶液を用い, 作用極には, それぞれ $\mathrm{Pt} / \mathrm{TiO}_{2}-\mathrm{SiO}_{2}$ $\left(\mathrm{TiO}_{2}: 5,10,50\right.$ mass\% $)$ を多孔質マイクロ電極に充填させ たものを使用した，その結果を図 7 の挿入図に示す。いずれ の電極触媒に抢いても酸化電流が観測されていることがわか る. 中でも, $\mathrm{Pt} / \mathrm{TiO}_{2}-\mathrm{SiO}_{2}\left(\mathrm{TiO}_{2}: 10\right.$ mass $\left.\%\right)$ が一番多く電
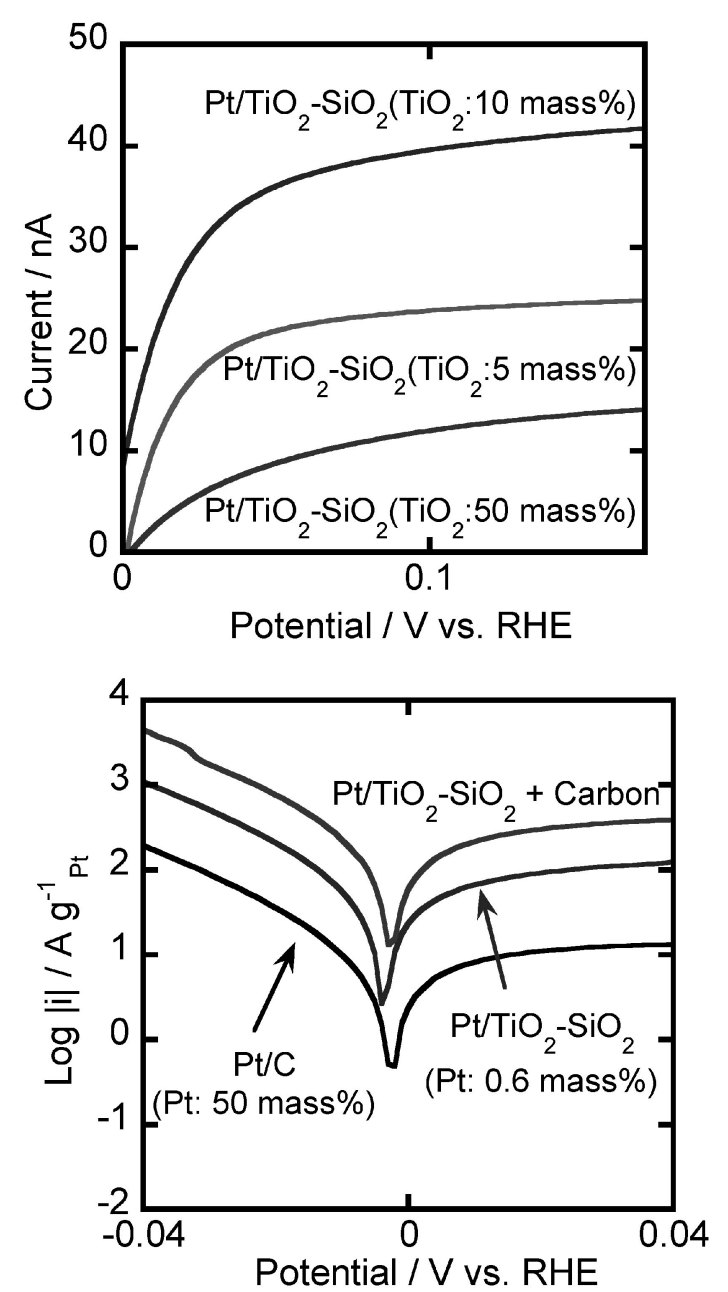

図 $7 \mathrm{Pt} / \mathrm{TiO}_{2}-\mathrm{SiO}_{2}\left(\mathrm{TiO}_{2}: 5,10,50 \mathrm{mass} \%\right)$ の水素酸化 反応の電流一電位曲線 (上図) と $\mathrm{Pt} / \mathrm{TiO}_{2}-\mathrm{SiO}_{2}$ $\left(\mathrm{TiO}_{2}: 10\right.$ mass \% ) と $\mathrm{Pt} / \mathrm{C}$ および $\mathrm{Pt} / \mathrm{TiO}_{2}-\mathrm{SiO}_{2}$ $\left(\mathrm{TiO}_{2}: 10\right.$ mass\% $\left.\%\right)+$ カーボンブラックの電流—電 位曲線(下図). 
流が流れている。この触媒の Pt 担持量は ICP 分析により 0.6 mass\%であることがわかった．そこで，市販の $\mathrm{Pt} / \mathrm{C}$ と $\mathrm{Pt}$ 量 $1 \mathrm{~g}$ 当たりで比較したところ図 7 より今回作製した電 極触媒の方が多くの電流が流れていることがわかった。 た，担持材料の導電性がカーボンブラックと比較すると劣る ため, $\mathrm{Pt} / \mathrm{TiO}_{2}-\mathrm{SiO}_{2}\left(\mathrm{TiO}_{2}: 10 \mathrm{mass} \%\right)$ 粉末にカーボンブラ ックを物理的に添加し混合したものも水素酸化反応を行っ た. その結果，カーボンブラックを添加しないものよりもさ らに高い電流を示すことがわかった。

\section{4.おわりに}

今回, Ptナノ粒子の簡易な担持手法と, 電極触媒として の展開の可能性を報告した。ささなる研究展開としては繰り 返し使用に抢ける寿命や耐久特性も重要である。また，高導 電性を有する担体材料の開発，抢よび安定性も必要である. 限りある資源を有効に活用し，よりよい持続的可能なエネル ギー社会への貢献につながる研究活動を続けていきたい.

最後に本稿で紹介した研究を遂行するにあたり, 大阪大学 大学院工学研究科の山下弘巳教授, 森浩亮准教授, 大阪府立 大学 21 世紀科学研究機構ナ八科学・材料研究センターの 亀川孝特別講師の御指導, 御助言を賜りました。 また, 長岡 技術科学大学大学院工学研究科の梅田実教授の御指導, 御助 言および研究室学生のご協力を賜りました．ここに深く感謝 の意を表します。

\section{文献}

(1) A. Cowley: Platinum 2013 Interim Review, Johnson Matthey, (2013).

(2) R. M. Rioux, H. Song, P. Yang and G. A. Somorjai: Metal Nanoclusters in Catalysis and Materials Science: The Issue of Size Control, Elsevier, (2008), 149-166.

(3) S. Shironita, K. Mori, T. Shimizu, T. Ohmichi, N. Mimura and H. Yamashita: Appl. Surf. Sci., 254(2008), 7604-7607.

(4) S. Shironita, K. Mori, T. Ohmichi, E. Taguchi, H. Mori and H. Yamashita: J. Nanosci. Nanotechnol., 9(2009), 557-561.

( 5 ) H. Yamashita and K. Mori: Chem. Lett., 36 (2007), 348-353.

(6) H. Yamashita, K. Ikeue, T. Takewaki and M. Anpo: Topics in Catal., 18(2002), 95-100.

( 7 ) W. Zhang, S. Shironita and M. Umeda: Catal. Lett., 144 (2014), 112-116.

( 8 ) M. Umeda, M. Kokubo, M. Mohamedi and I. Uchida: Electrochim. Acta, 48(2003), 1367-1374.

(9) A. J. Bard and L. R. Faulkner: Electrochemical Methods: Fundamentals and Application, Wiley, (2000).

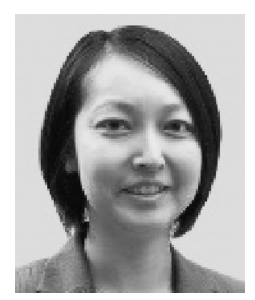

白仁田沙代子

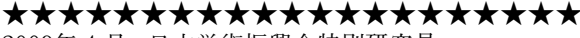
2009年 4 月 日本学術振興会特別研究員 2009 年 9 月 大阪大学大学院工学研究科博士後期課程 修了

2010年 4 月- 現職

専門分野：電気化学, 触媒化学

（高活性な金属表面を確保するための金属ナノ粒子化 技術の開発と金属表面の劣化機構解明に従事.レア メタルの省資源化抢よび水素エネルギー社会構築へ
の貢献を目指した研究活動. 